\title{
Children's Social Skills Stimulation Viewed From Early Childhood Education Unit in Indonesia
}

\author{
Aulia Rohmawati
}

\begin{tabular}{l} 
ARTICLE INFO \\
\hline Article History: \\
Received 05.05.2018 \\
Received in revised form \\
26.06.2018 \\
Tarih girmek için buray1 \\
tiklatın. \\
Available online 01.07 .2018
\end{tabular}

\begin{abstract}
Social skill is the most important aspects in the children development to determine them for starting to and getting social interaction to among others. An Early Childhood Education is a strategic place to develop children's social skill. Each of Early Childhood Education levels has some ways and own methodologies to emerge social values including stimulation of social skill.This research uses qualitative methodology. Collect the data using interview, observation, documentation as well as validate data using triangulation and resource. Data analy sis include data collection, data reduction, data serving, data concluding and verification. The result of this research shows that (1) Stimulation of social skill is given through daily activity in the school according to own ty pes of institution; (2) Teachers are able to arrange timetable, have an authority to determine what ty pe of stimulation are needed as well as supervise and control the implementation of it. Suggestion for this research are proposed to: (1) Institutions are hopefully facilitating more proper to stimulate social skills in the children; (2) Teachers are hopefully making a varied timetable and making an outstanding activity to stimulate social skills in the children; (3) Parents are hopefully cooperating with the teachers to emerge independence in their children.
\end{abstract}

C 2018IJERE. All rights reserved

Keywords:

Children, Social Skills Stimulation, Early Childhood Education Unit.

\section{INTRODUCTION}

Early childhood is a child in the age of 0-6 years (UU No.20 Tahun 2003). Early childhood were at the stage of growth and development, both physically and mentally. At first the children were born not have a social nature, which means children do not have the ability to interact with other people. As social beings, an individual from birth to throughout his life alw ays in touch with others or make interpersonal relationships (Mutmainah, 2012). As social beings, children are required to be able to overcome various problems that arise as a result of interaction with the social environment and able to present themselves in accordance with the rules of the norm (Bachri, 2010).

Social skills is one aspect of early childhood development that very important in determining the success of a child to start and have social relationships with other people. Social skills is a behavior form, actions and attitude that displayed by individuals when interacting with other people that do properly so it can provide a comfort feel for people surroundings. In the beginning, children do not have a social nature, which means children do not have the ability to use others. Social and emotional learning (SEL) interventions usually focus on a variety of factors including alternative problem solving thinking skills, social competence, social behaviors (Greenberg, Domitrovich, Karabay, Tuncdemir, and Gest, 2018). The social abilities of children will be formed along with the interaction with the people in the child's environment, because human beings are actually social beings who have the urge to connect with other human beings. The need to turn with others begins when the children are three months old, where children can begin to mingle with the nearest (mothers / fathers), fold the voice of the nearest person (mother / father) (Permendikbud No. 137 Tahun 2014 Lampiran I).

Children who master the social skills well is expected to conform with group norms so that they can interact properly and accepted by the environment around the child. Early Childhood Education (ECE) is a coaching effort that directed to children from birth until the age of six years that which accomplished by providing educational stimulation to help the growth and development of children's physically and mentally in order to have the readiness to enter further education (UU No. 20 Tahun 2003). Pre-school education has considerable importance within contemporary education understanding. Each unit of the school institution has its own way of learning models (Çevik, 2017). Also with early childhood education units that have a lot of bases with varied learning models. Each of these early childhood institutions in 
Indonesia have the right to develop a learning model which applied to each school. Either it Kindergarten (TK), Raudlatul RA (RA), and Bustanul Athfal (BA) has its own distinctive characteristics and methods in instilling social values, including social skills stimulation (Permendikbud Tahun 2014 Nomor 137). Based on this background, the problem in this research are: (1) how is the providing of social skills stimulation in children view ed from early childhood education institute units, (2) how is the teacher's role in providing the children social skills stimulation viewed from early childhood education units. This research aims to (1) determine, explain and illustrate the differences social skills stimulation of children viewed from early childhood education units. (2) to determine the role of teachers in providing children's social skills stimulation viewed from early childhood education units.

\section{METHOD}

This research is using qualitative research methods. Bogdan and Taylor (as cited in Moleong, 2006), states that qualitative research is a research procedure that produces descriptive data in the form of spoken words from the people and the observed behavior.

Qualitative research methods performed in a reasonable situation and the collected data generally qualitative. Qualitative methods are more based on the philosophy which uses phenomologis appreciation and trying to understand and interpret the meaning of an interaction human behavior event in specific situations according to the researcher's own perspective. The study involved 165 children aged 4-6 years in Class A, Class B1, and class B2 in Early Childhood Education.

The location of this research is in the kindergarten institution at Pertiwi Andong Kindergarten, Raudlatul Athfal on RA Perwanida 03, and Bustanul Athfal on Aisyiyah 1 Andong Kindergarten Andong District Boyolali Regency, Indonesia. The technique of collecting data through observation, interview s, and documentation. The data analysis that used in this research coincides with the data collection process, the process of collecting data use data reduction, data presentation, and giving conclusion and verification.

\section{RESULT}

Based on observations and interviews, obtained results that social skills stimulation that given to each of Early Childhood Education institutions have similarities and differences. Similarities on provided social skills stimulation on the three institutions is a stimulation that given through daily learning activities. The daily activities in the form of activities to share and play together. From the shared experience of others, the students on Aisyiyah 1 Kacangan Kindergarten, Pertiwi Andong Kindergarten, and RA Perwanida 03 Mojo knows that one way to gain social approval is to divide his property, especially toys for other children, slowly turned nature themselves into generous nature. The children at three institutions are taught to be able to share something that belonged to him so that children can be accepted by the social groups in the school environment. Storytelling activities or storytelling also given by teachers to instill the values of the importance of social skills. Trianto (2011) argues storytelling is activities such as listening to verbal utterances which tells the story of an event. This method for developing imagination, intellect, emotions, and child language acquisition. Some other strategies are also applied to teachers in providing stimulation social skills to students in the daily learning. This following strategies is a way to encourage the social skills development according to Ormrod (2008):

1. Provide many opportunities

The students acquire the knowledge of effective and ineffective social behavior in a direct way to interact with each other. A variety of tasks and activities that require students to cooperate tow ards a common goal to help the development of skills to help and share (helping-giving) and improve students' knowledge about the importance of being fair and honest among peers (Damon, Lickona, Webb \& Farivar, as cited Ormrod, 2008).

2. Helps to interpret social situations

When students consistently have problems in intercommunication, explicit training on social cognition can make a difference. For example, in a study (Dudley \& Graham as cited in Ormrod, 2008), the male children from two seedy neighborhood and income render follow a series of training sessions through role play, discuss the personal experiences, brainstorming, and some similar activities, they practice creating inferences about the other people intentions and identify to act in proper ways.

3. Teach specific social skills 
Teachers teach student a proper steps to act through specific verbal instructions and through modeling (i.e. direct) behaviors that we want. The only instructions will becomes more effective when the teacher asked them to practice social skills they had just learned (perhaps through role play) and give them concrete feedback on their performance (Elliot \& Busse, Themann \& Goldstein, Vaughn, Zirpoli\& Melloy, as cited in Ormrod, 2008).

4. Provide feedback to the appropriate behaviors

Children will get a deeper understanding about a good social behavior if we specifically show what they have to do properly (Vorrath, Wittmer \& Honig, as cited in Ormrod, 2008). For example, we can say "thank you, you've been very helpful" or "I'm proud both of you can work so well in this task".

5. Establish strict rules

Besides encouraging the appropriate social behaviors, teachers also actively prevent (discourage) behaviors that do not appropriate such as indifference, aggressive and prejudiced attitude. We must have clear guidelines on behavior in the classroom and provide specific consequences when the rules are violated. (Bierman, Miller, \& Stabb, Braukmann, Kirgin, \& Wolf, Schofield, as cited in Ormrod, 2008).

However, because the three Childhood Education institutions is an institution that has a different background, then they also have some differences in providing social skills stimulation. The difference lies on Aisyiyah 1 Kacangan Kindergarten which implemented a seating moved system, allowing parents to waiting their children, and train children to give the distance between male and female, Pertiwi Andong Kindergarten which has a Drum band Extra activities to develop children's social skills, and RA Perwanida 03 Mojo which positioned the teacher as a children friendly friends, cheerful, and not intimidating. Although using the same storytelling methods to develop the children social skills, but each teacher has their own methods and media in conveying the story.

The existence of these differences does not make the children in each of the early childhood education institutions have difficulty in developing social skills. Each children in these institutions have a preety good skills that appropriate with the development stages. Caldarella and Merrell in Setiani (2014) suggests five (5) most commonly dimensions that found in social skills, which is also owned by the students on Aisyiyah 1 KacanganKindergarten, Pertiwi Andong Kindergarten, and RA Perw anida 03 Mojo, that is :

a) Peer relation, shown through a positive attitude to peers such as praise or advising others, offer help to others, and play with others.

b) Self-management, reflect a student who has a good emotional, who is able to control his emotions, follow the rules and restrictions that exist, can take criticism well.

c) Academic, shown through the fulfillment of tasks independently, completing individual tasks, running teacher's direction w ell.

d) Compliance, showed a student who can follow the rules and expectations, using the time well, and share something.

e) Assertion, dominated by the abilities that make a teen can display appropriate behavior in a situation that is expected.

Generally the students in Aisyiyah 1 Kacangan Kindergarten, Pertiwi Andong Kindergarten, and RA Perwanida 03 Mojo have a good social skills. The role of the school is supported by educators who developed the children social skills by providing appropriate stimulations is a very influential factor for the creation of children social skills.

\section{CONCLUSION}

In summary, Social skills stimulation that given by Aisyiyah 1 Kacangan Kindergarten, Pertiwi Andong Kindergarten, and RA Perwanida 03 Mojo has some similarities to the stimulation of social skills is given through daily activities. While the difference lies on Aisyiy ah 1 Kacangan Kindergarten which implemented a seating moved system, allowing parents to waiting their children, and train children to give the distance between male and female, Pertiwi Andong Kindergartenwhich has a Drum band Extra activities to develop children's social skills, dan RA Perwanida 03 Mojo which positioned the teacher as a children friendly friends, cheerful, and not intimidating. The results indicated the children in the schools have had a fairly good level of social skills.

Each teacher at the institute Aisyiyah 1 Kacangan Kindergarten, Pertiwi Andong Kindergarten, and RA Perwanida 03 Mojo have a role such make plans of activities, given full confidence to choose the 
Rohmawati,A. (2018).Children's social skills stimulation viewed from early childhood education unit in Indonesia. International Journal of Educational Research Review,3(3),69-73.

stimulation of social skills such as what will be given to the students, and provide supervision to control the implementation of child's social skills stimulation. The difference lies in their respective teachers in selecting media storytelling to embed an understanding of the importance of social skills in children. Since the stimulation of social skills is left entirely to the teacher, the teacher must be creative in choosing good and interesting activities for the child.

\section{REFERENCES}

Arikunto, S. (2006). Prosedur penelitian. Jakarta: PT Rineka Cipta.

Bachri, S.T.M. (2010). Psikologi pendidikan berbasis analisis empiris aplikatif. Jakarta: Kencana Prenada Media Group.

Çevik, G. B. (2017). Examining pre-school teachers' and parents' views on counseling and guidance services in pre-school education. International Journal of Evaluation and Research in Education (IJERE), 207-215.

Fatmawati, E. (2011). Implementasi Pendekatan Selaras Perkembangan (DAP) dalam Pembelajaran Keterampilan Sosial Anak Usia 4 Sampai 6 Tahun (Studi Deskriptif Pada TK Negeri Pembina dan TK Kemala Bhayangkari Kabupaten Brebes), 2011. Skripsi PG PAUD Unnes: Unpublished.

Hasan, I. (2002). Pokok-Pokok materi metodologi penelitian dan aplikasinya. Jakarta: Ghalia Indonesia.

Hurlock, E. B. (1980). Psokologi perkembangan suatu pendekatan sepanjang rentang kehidupan. Jakarta: Erlangga.

Kaelan. (2005). Metode penelitian bidang filsafat. Yogyakarta: Paradigma.

Kamus Besar Bahasa Indonesia Edisi Ketiga. (2002). Jakarta: Balai Pustaka.

Greenberg,M.,Domitrovich,C.,Karabay,S.O,,Tunçdemir,T.B.A. \& Gest,S.(2018). Focusing on teacher-children relationship perception and children's social emotional behaviors - the paths preschool program. International Journal of Evaluation and Research in Education (IJERE) , 3(1),8-20.

Mutmainah, S. (2012). Perilaku sosial anak usia dini berambuat gimbal di daerah dataran tinggi dieng kabupaten wonosobo. Indonesian Journal of Early Childhood Education Studies (IJECES), 50.

Moeloeng, L.J. (2009). Metode penelitian kualitattif. Bandung: PT Remaja Rosdakarya.

Ormrod, J. E. (2008). Edisi keenam psikologi pendidikan membantu siswa tumbuh dan berkembang. Jakarta: Penerbit Erlangga.

Purwanto. (2008). Metodologi penelitian kuantitatif untuk psikologi dan pendidikan. Yogyakarta: Pustaka Pelajar.

Setiani, T. (2014). Peningkatan keterampilan sosial siswa melalui penerapan metode simulasi pada pembelajaran ips kelas $v$ sd negeri pakem 2 sleman. Skripsi PGSD UNY: Unpublished.

Silalahi, U. (2009). Metode penelitian sosial. Bandung: PT Refika Aditama.

Sugiyono, P. (2009). Metode penelitian kuantitatif kualitatif dan RED. Bandung: Alfabeta.

Sukasih. (2015). Social studies introduces "Good Citizen" since kindergarten.Indonesian Journal of Early Childhood Education Studies (IJECES), 60.

Suyadi. (2014). Teori pembelajaran anak usia dini dalam kajian neurosains. Bandung: PT Remaja Rosdakarya Offset.

Trianto, M. (2011). Desain pengembangan pembelajaran tematik bagi anak usia dini TK/RA \& Anak Usia Kelas Awal SD/MI. Jakarta: Kencana Prenada Media Group.

Wiyani, N.A. (2014). Psikologi perkembangan anak usia dini panduan bagi orang tua dan pendidik PAUD dalam memahami serta mendidik anak usia dini. Yogyakarta: Gava Media. 
Rohmawati,A. (2018).Children's social skills stimulation viewed from early childhood educa tion unit in Indonesia. International Journal of Educational Research Review,3(3),69-73.

Yamin, M.M., \& Sanan J.S.M. (2010). Panduan Pendidikan Anak Usia Dini. Jakarta: Gaung Persada (GP) Press. Permendikbud Tahun 2004 No. 137.

UU No. 20 Tahun 2003. 